\title{
Emerging Perspectives in Labour Regulation in the Wake of COVID-19
}

\author{
Kamala Sankaran ${ }^{1}$ (iD \\ Published online: 7 September 2020 \\ (c) Indian Society of Labour Economics 2020
}

The present COVID-19 crisis has shifted to centre-stage the question of work and workers after a long time. It has brought back the focus onto what are (or should be) basic rights in the world of work and the manner in which we regulate business. This short paper argues that the crisis provides us the opportunity to take necessary corrective steps in India's regulatory framework, in line with our constitutional provisions and international obligations, and keeping in mind the perspective of those in formal and informal employment.

\section{Reforms Underway in Response to the COVID-19}

The lockdown and the resultant loss of employment have been some of the biggest challenges of the COVID crisis. On the one hand, we have the haunting images of the returning migrant workers and their families trudging home hundreds of miles as the defining images of the COVID crisis in India. On the other hand, various state governments have put in place measures that seek to be business-friendly, to improve the perceived rigidities of the labour market, and to reduce labour protection, as part of efforts to revive industry and employment. Between April and May 2020 , over 10 states sought to extend working hours to between 10 and $12 \mathrm{~h}$ a day and/or increase the employment threshold for payment of retrenchment, closure, or lay-off compensation, and, in some cases, to revoke most labour laws. ${ }^{1}$ The idea

\footnotetext{
${ }^{1}$ For details, see Bharat Ram, A., Relaxation of labour laws across states, available at https://www. prsindia.org/theprsblog/relaxation-labour-laws-across-states. Also see Shyam Sundar, K.R., Sapkal, R.S., (2020). Changes to labour laws by State Governments will lead to anarchy in the labour market. EPW Engage, 55(23).
}

This is a revised version of the presentation at the IHD-ISLE-ILO Virtual Conference on Implications of the COVID-19 Crisis for Labour and Employment in India: Impact, Strategies and Perspectives, 8-9 June 2020. I am grateful for the comments and questions received during the presentation. Errors remain mine.

Kamala Sankaran

kamala.sankaran@gmail.com

1 Campus Law Centre, Faculty of Law, University of Delhi, Delhi, India 
that labour regulation is 'costly', distorts the market, creates labour inefficiencies, comes up in public and policy discourse with unfailing regularity, even though there is scant published evidence backing such notions. On the contrary, there are studies which point to the positive effects of regulating unequal bargaining parties and of a protective floor in unequal labour markets. ${ }^{2}$

At the central level, the government has been pushing ahead with its consolidation exercise of labour laws, seeking to reduce the over 44 central labour laws (and many more state laws and state-level amendments to central laws) into four Codes covering wages, social security, OSH (occupational safety, health and working conditions), and industrial relations. The COVID crisis has seen a legislative and policy response, and is perceived as a moment to 'reset' the regulatory framework. The question is what direction and shape should this change in the regulatory framework take.

\section{The Constitution and Its Framework for Regulation}

It is useful to examine any proposed shift in law and policy against the constitutional framework. Given the separation of powers in our constitutional scheme, every policy and legal change, however, urgently pushed through, is likely to be tested in the legislature, say, when an ordinance is transformed into law, or when statutory rules made by the executive are placed for approval. Yet, often, the greater challenge for any governmental initiative arises from the judiciary, with its role as the sentinel on the qui vive ${ }^{3}$ and as the final interpreter of the Constitution.

At the time of the drafting of our Constitution (1946-1949), there was a remarkable consensus across the political spectrum that the yet-to-be drafted Indian Constitution should have a comprehensive set of rights that would include not only negative political liberties but also the social rights that would be essential for a social transformation of the country. The eventual Constitution, as adopted, had justiciable fundamental rights guaranteeing the more classical civil liberties, while the positive socio-economic and other programmatic rights were treated as non-justiciable Directive Principles of State Policy (DPSP).

The scope of fundamental rights has been broadened gradually by judicial interpretation keeping the DPSP in mind. Thus, the Supreme Court has interpreted Article 21 (providing for the right to life and personal liberty) to declare that there is a right to livelihood in India, which is a part of the right to life. Speaking for a fivejudge bench in Olga Tellis Vs. Bombay Municipal Corporation (1985) Chandrachud CJ declared: If the right to livelihood is not treated as a part of the constitutional

\footnotetext{
${ }^{2}$ See, for instance, Deakin, D. (2011). Theevidence-based case for labour regulation. In Lee, S., McCann, D., (eds.) Regulating for decent work: New directions in labour market regulation (pp. 31-57). Palgrave Macmilan/ILO; 1 D’Souza, E. (2008). Labour market institutions in India: Their impact on growth and employment New Delhi: ILO; Bhattacharjea, A., (2009). The effects of employment protection legislation on Indian manufacturing. Economic and Political Weekly, 44(22), 55-62.

3 M. Patanjali Shastri CJ in State of Madras v. V.G. Row, [1952] S.C.R. 597.
} 
right to life, the easiest way of depriving a person his right to life would be to deprive him of his means of livelihood to the point of abrogation. ...Deprive a person of his right to livelihood and you shall have deprived him of his life. Indeed, that explains the massive migration of the rural population to big cities. ${ }^{4}$

Given that the constitutional right to life entails the right to livelihood, what duty does it cast upon the State, society, and employer? The constitutional right to livelihood does not always expand into a right to demand work in India (except where a statutory right is provided, as under the MNREGA, 2005). ${ }^{5}$ For those able to obtain waged employment, the constitutional principles of dignity, non-discrimination, and non-exploitation would require even private employers to ensure safe work conditions, minimum wages, and social security. A more proactive understanding of the right to earn one's livelihood is needed for those people whose lives are precarious because they lack regular waged employment. A broader idea of the right to work as encompassing the right to pursue one's livelihood, and also including the right to obtain state largesse in the form of subsidies to set up one's own business, the access to loans and facilities for this purpose, and the enhancement of one's capabilities to achieve self-employment has rarely been the subject matter of 'rights talk' or of labour regulation. Many persons are in these vulnerable circumstances, often due to decisions taken by the State (and, in which they had no voice) that result in their impoverishment, or their increased vulnerability, or because of an unequal 'original position'. It is precisely because the power, to make economic and social decisions which can impinge the lives of so many persons, lies with the State that this gives rise to the duty upon the State to provide for social assistance, as is captured so well in Article 41 of the Constitution. ${ }^{6}$

The recent move to dilute, or drop altogether, labour laws for a period, in order to position the country or a specific state as an attractive destination for investment, indicates how much traction this idea of deregulation has over the minds of our policy makers. However, this choice, of whether or not to have regulations relating to decent working hours or conditions, is not one to be exercised by the governments of the day. These larger choices have already been taken in the Constitution and cannot be waived or overridden. I argue, therefore, that the minimum conditions of universal protection provided by the regulatory framework are a constitutional duty and must form the core of any labour regulation in India. Further, India's obligations

\footnotetext{
${ }^{4}$ In arriving at this interpretation, the SC relied on various DPSPs. Article 39(a) of the Constitution, which provides that the State shall, in particular, direct its policy towards securing that the citizens, men and women equally, have the right to an adequate means of livelihood; Article 41 provides that the State shall, within the limits of its economic capacity and development, make effective provision for securing the right to work, to educaton and to public assitance in cases of unemployment, and old age, sickness and disablement, and in other cases of undeserved want. Article 37 provides that the Directive Principles, though not enforceable by any court, are nevertheless fundamental in the governance of the country. This provision has been central to judicial oversight in these matters.

${ }^{5}$ For the limited nature of the right to livelihood in India, see Sankaran, K. (2012). The human right to livelihood: Recognizing the right to be human. Comparative Labor Law \& Policy Journal, 34 (1), 81-94.

6 See footnote 4.
} 
to the ILO are another aspect that prevents the scenario of a race to the bottom that some of the proposed labour reforms envisage.

\section{Direction for Future Reforms of Labour Regulation}

Arising out of this constitutional perspective, let me briefly suggest some perspectives that need to be kept in mind while navigating this important historical moment, when India is revamping its regulatory framework for labour and business.

1. The Codes currently under discussion in Parliament (including the already enacted Code on Wages) need a re-look, to address increased harmonisation. A look at the Codes would indicate how they have stitched together pre-existing laws, not always harmonising them. The draft OSH Code refers to both 'workers' and 'employees', in addition to audio visual worker, building worker, contract labour, motor transport worker, sales promotion employee, etc. Yet, some Codes ignore domestic workers and unpaid workers, apart from the selfemployed The tremendous discretion granted to the executive to unilaterally modify provisions in the Codes, without prior consultation with tripartite partners, or legislative approval (as has been the case in the recent past when the hours of work were increased).

2. The transition to formalisation of workers (not merely of enterprises) requires a focus on inclusivity in the Codes, and universal access to social security and social assistance. Financing of social security cannot be based only on social solidarity of the workers in an industry. It needs to be broadened beyond the earlier models, which are either employer-liability-centric or social-insurance based, and to draw instead on the value chain of the industry concerned. Such models can be adapted more easily to provide social security to the vulnerable self-employed, or what are termed 'dependant' contractors. This broadening is particularly important in the emerging gig economy, where clear-cut employeremployee relations are not visible.

3. No doubt labour laws have the pride of place in regulating labour, but the regulatory regime also covers other branches of law (competition laws, investment law, municipal laws, to mention a few), and any regulatory solution must factor in that aspect. This is especially true when dealing with self-employed persons, where occupational safety and conditions of work are not determined in workplaces provided by an employer, but may require provisioning of hygiene and safety in urban areas, access to spaces regulated by municipal laws in the case of street vendors, or provisioning of housing in the case of home workers. The emergence of the platform and gig economy is often regulated by competition law, as in the case of cab aggregators, and labour regulation needs to incorporate such a broadened field of operation.

4. Increasingly, recently enacted laws such as the Unorganised Workers Social Security Act, 2008, or the Street Vendors (Protection of Livelihood and Regulation of Street Vending) Act, 2014, are marked by an absence of robust com- 
plaint procedures, inspection systems, or grievance redressal procedures. These absences continue in the Codes. The use of the inspector-cum-facilitator device in the Codes, and the absence of independent powers to inspect without prior permission and to initiate action, as required under ILO Convention No 81, needs to be urgently addressed.

Publisher's Note Springer Nature remains neutral with regard to jurisdictional claims in published maps and institutional affiliations. 